\title{
Metabolic clearance and production rates of oestradiol and progesterone during pubertal and postpubertal development in gilts
}

\author{
R. K. Christenson, J. J. Ford and D. A. Redmer* \\ U.S. Department of Agriculture, Agricultural Research Service, Roman L. Hruska U.S. Meat Animal \\ Research Center, Clay Center, Nebraska 68933, U.S.A.
}

\begin{abstract}
Summary. The crossbred gilts studied were aged 80 days (prepubertal), 180 days (prepubertal or postpubertal) and 260 days (postpubertal or pregnant). Estimates of metabolic clearance rate (MCR) of oestradiol and progesterone were consistently less (21 and $27 \%$ ) in plasma than in blood, and these differences were not influenced by age of gilt. The MCR (l/day per kg body weight) for oestradiol and progesterone in plasma was greater $(P<0.05)$ for 80 -day-old prepubertal gilts than for older gilts. The MCR values of oestradiol and progesterone were similar in 180-day-old and 260-day-old gilts independent of reproductive state. Production rate (PR) of oestradiol and progesterone increased with age (80-180 days), and age and reproductive state differences were much more pronounced for PR of progesterone than of oestradiol. These results support the hypothesis that a reduction in the MCR and an increase in PR of oestradiol and progesterone in the gilt are associated with the process of pubertal development, and changes in gonadal steroid concentrations appear not to alter the MCR of oestradiol and progesterone.
\end{abstract}

\section{Introduction}

Studies with female and male pigs (Elsaesser, Stickney \& Foxcroft, 1982; Christenson, Ford \& Redmer, 1984) and the female rhesus monkey (Hotchkiss, 1983) have shown that immature animals metabolize steroids (per $\mathrm{kg}$ body weight) at a faster rate than do older, mature animals. In immature boars there is also a low production rate (PR) of steroids (Christenson et al., 1984) which suggests that the availability of steroids could be a limiting factor for sexual development.

Little is known about steroid metabolism in pigs. The primary site of metabolism is assumed to be the liver; however, during growth and development of the pig, it is not known whether the hepatic steroid metabolism is a developing or static process. Two classes of hepatic enzymes involved in steroid metabolism are the cytochrome P-450-containing oxidative enzymes (mixedfunction oxidases) and $5 \alpha$ - and $5 \beta$-reductase activity (Colby, 1980). Several studies of adult rats have shown sex differences in hepatic enzyme activities. These sex differences have been attributed to the action of androgens during prepubertal development. Female rats show greater $5 \alpha$-reductase activity, whereas males, in general, exhibit greater hydroxylating activity (see Colby, 1980, for review). This suggests that hepatic steroid metabolism is a developmental process during maturation and, in the rat, certain steroids (androgens) influence hepatic enzymes that are responsible for metabolism of drugs and steroid hormones. However, Christenson et al. (1984) reported that intact and neonatally ( 35 days) castrated boars had similar metabolic clearance rate (MCR) values for oestradiol-17 $\beta$ (oestradiol) and testosterone determined at 180 days of age. It is not known whether

\footnotetext{
* Present address: Department of Animal Science, North Dakota State University, Fargo, ND 58105, U.S.A.
} 
steroid hormones in pigs influence the development of steroid clearance or whether acute changes in steroid hormone concentration alter MCR during different reproductive states.

The purpose of this experiment was to evaluate the relationship of MCR of gonadal steroids to age and to different reproductive states at a constant age in gilts.

\section{Materials and Methods}

Animals. Crossbred (Chester White:Large White $\times$ Yorkshire:Landrace reciprocal cross) gilts were assigned to the experiment at three ages (80,180 or 260 days). Five gilts were assigned to the 80-day-old prepubertal group. The 180- and 260-day-old gilts were subdivided (4-6 gilts per group) into 180-day prepubertal or postpubertal (Day 7 of the oestrous cycle) and 260-day postpubertal (Day 11 of the oestrous cycle) or pregnant (30 days of gestation) groups, respectively. Gilts were fed a corn:soybean ration twice daily at $07: 30$ and $16: 00 \mathrm{~h}$ and water was always available. Gilts were catheterized 5 days before experimentation and moved to individual stalls on an elevated deck in a confinement building. Catheterization procedures and catheter materials (Teflon for infusion, $0.75 \mathrm{~mm}$ i.d.: Dupont, Wilmington, DE; Tygon micro-bore for sampling, $1.27 \mathrm{~mm}$ i.d.: Norton Co., Akron, $\mathrm{OH}$ ) were as reported for a previous study of boars (Christenson et al., 1984).

Beginning 4 days after catheterization, twice daily $(08: 00$ and 16:00 h) blood samples $(10 \mathrm{ml})$ were collected into heparinized syringes, cooled on ice, centrifuged and the plasma was frozen for later determination of oestradiol and progesterone concentrations. On the 5 th day, at 08:00 h, an initial blood sample $(10 \mathrm{ml})$ was collected and duplicate haematocrit determinations were made before centrifugation and plasma storage. In unanaesthetized gilts, a continuous infusion of $\left[2,4,6,7,16,17,-{ }^{3} \mathrm{H}\right]$ oestradiol-17 $\beta$ (New England Nuclear Corp., Boston, MA) was initiated through the Teflon catheter by using a sterile disposable syringe $(60 \mathrm{ml})$ and a syringe infusion pump (Harvard Apparatus Co., Millis, MA). The infusate consisted of $150 \mu \mathrm{Ci}\left[{ }^{3} \mathrm{H}\right]$ oestradiol in $75 \mathrm{ml}$ sterile $0.9 \%(\mathrm{w} / \mathrm{v}) \mathrm{NaCl}$ solution, which was infused at a rate of $0.35 \mathrm{ml} / \mathrm{min}$ for $175 \mathrm{~min}$. The infusate $(1.27 \mathrm{ng} / \mathrm{min})$ represents $3-5 \%$ of oestradiol production rate. Infusion pumps were checked periodically to ascertain the constancy of the rate of infusion during the 2-3-h infusion period. At 15, 45, 75, 90, 105, 120 and 135 min after the start of the infusion, blood samples ( $5 \mathrm{ml}$ ) were collected, immediately centrifuged, and $200 \mu \mathrm{l}$ plasma were added to scintillation cocktail (Budget-Solve: Research Products International Corp., Mount Prospect, IL) and counted in a liquid scintillation spectrometer. At 145, 155, 165 and $175 \mathrm{~min}$ after the initiation of the infusion, blood samples of $10 \mathrm{ml}$ were collected for determination of $\left[{ }^{3} \mathrm{H}\right]$ oestradiol concentration in blood and plasma. At the end of the infusion (175 min), triplicate I-min samples of the infusate were collected in 100-ml volumetric flasks from the Teflon infusion tubing to quantify the amount of $\left[{ }^{3} \mathrm{H}\right]$ oestradiol infused. Two days later the infusion and sampling procedures were repeated using $\left[1,2,6,7,21-{ }^{3} \mathrm{H}\right]$ progesterone (New England Nuclear) as the infusate $(1 \cdot 36 \mathrm{ng} / \mathrm{min})$.

Hormone determinations. Blood samples (collected at 145-175 min) and 1-min infusate samples were immediately placed on ice and processed within $2 \mathrm{~h}$ on the day of collection. Samples collected during the $\left[{ }^{3} \mathrm{H}\right]$ oestradiol infusion were processed as described by Christenson et al. (1984). Blood and infusate samples collected during the $\left[{ }^{3} \mathrm{H}\right]$ progesterone infusion were processed within $2 \mathrm{~h}$ by the following procedures. Duplicate $1-\mathrm{ml}$ volumes of each of the four blood samples were added to 15 -ml extraction tubes that contained $1 \mathrm{ml}$ distilled water which lysed the blood cells. The remaining $8 \mathrm{ml}$ of each blood sample were centrifuged and two $1-\mathrm{ml}$ volumes of plasma were added to extraction tubes. The three $1-\mathrm{min}$ infusate samples were diluted to $100 \mathrm{ml}$ with saline and $1-\mathrm{ml}$ volumes were added to extraction tubes. Each extraction tube received approximately 500 c.p.m. $\left[{ }^{14} \mathrm{C}\right]$ progesterone to estimate losses during extraction and after a 30 -min equilibration at room temperature $100 \mu \mathrm{l} 1 \mathrm{M}$-sodium hydroxide were added. Samples were extracted twice with $5 \mathrm{ml}$ 
diethyl ether. The resultant extracts were chromatographed on Sephadex LH-20 columns as described by Carr, Mikhail \& Flickinger (1971) and progesterone was eluted with heptane:chloroform: methanol ( $85: 5: 10$, by vol.).

Radioactivity in the column eluates was quantitated by dual-label scintillation counting techniques. The recoveries for $\left[{ }^{14} \mathrm{C}\right]$ oestradiol and $\left[{ }^{14} \mathrm{C}\right]$ progesterone from the columns averaged 76 and $79 \%$ for blood and 81 and $83 \%$ for plasma, respectively. Oestradiol and progesterone MCR determined in blood and plasma were calculated according to Tait (1963) as described by Christenson et al. (1984) and expressed as litres per day (l/day) or litres per day per kg body weight $\left(1 / \mathrm{day} \cdot \mathrm{kg}^{-1}\right)$. Plasma production rates were calculated as the products of the plasma oestradiol or progesterone concentration and the plasma MCR (1/day) of oestradiol or progesterone, respectively.

Concentrations of plasma oestradiol were determined by radioimmunoassay (Christenson $e t$ al., 1984). Minimum sensitivity of the assay was $6 \mathrm{pg} / \mathrm{ml}$ and inter-assay coefficients of variation for two pools (high and low concentration) of gilt serum were 7.7 and $16.5 \%(n=6)$. Concentrations of progesterone were determined in duplicate 400 or $25 \mu \mathrm{l}$ samples of plasma from prepubertal and postpubertal gilts, respectively, by procedures described by Christenson (1981), using a rabbit antiserum developed against progesterone-11 $\alpha$-bovine serum albumin (Miles Laboratories, Inc., Elkhart, IN). Minimum sensitivity was $10 \mathrm{pg}$ per assay tube. The inter-assay coefficient of variation for a pool of gilt serum $(10 \mathrm{ng} / \mathrm{ml})$ was $4.9 \%(n=2)$.

Statistical analysis. Data were tested for homogeneity of variance and, when heterogeneity was apparent, data were transformed to logarithms. Data were analysed by one-way analysis of variance, and differences in treatment means were tested by the Newman-Keuls' test (Steel \& Torrie, 1960).

\section{Results}

Equilibration of plasma concentrations of $\left[{ }^{3} \mathrm{H}\right]$ oestradiol and $\left[{ }^{3} \mathrm{H}\right]$ progesterone for gilts of all ages is presented in Text-fig. 1. Equilibration during the continuous infusion of $\left[{ }^{3} \mathrm{H}\right]$ oestradiol and

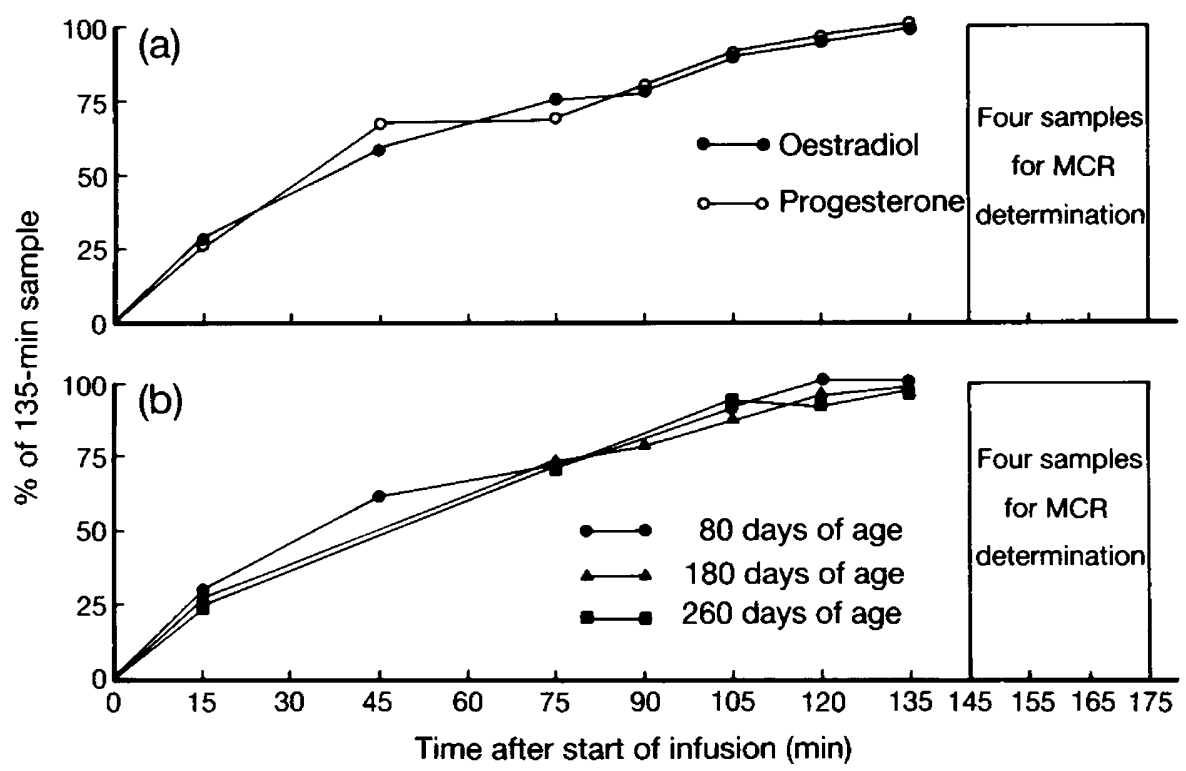

Text-fig. 1. Equilibration of $\left[{ }^{3} \mathrm{H}\right]$ oestradiol and $\left[{ }^{3} \mathrm{H}\right]$ progesterone in plasma of $80-, 180$ - and 260-day-old gilts continuously infused for $175 \mathrm{~min}$. In (a), the percentages for the 3 ages of gilts were pooled per hormone. In (b), the percentages for the 2 hormones were pooled per age. 
Table 1. Metabolic clearance rate, plasma concentration and production rate of oestradiol in gilts of different ages and reproductive states

\begin{tabular}{|c|c|c|c|c|c|c|}
\hline \multirow{2}{*}{$\begin{array}{l}\text { Age } \\
\text { (days) }\end{array}$} & \multirow{2}{*}{$\begin{array}{l}\text { No. of } \\
\text { gilts* }\end{array}$} & \multirow[b]{2}{*}{ Status } & \multicolumn{2}{|c|}{$\begin{array}{l}\text { Plasma metabolic } \\
\text { clearance rate }\end{array}$} & \multirow{2}{*}{$\begin{array}{l}\text { Plasma } \\
\text { oestradiol } \\
\text { conc. } \\
\text { (pg/ml) }\end{array}$} & \multirow{2}{*}{$\begin{array}{l}\text { Plasma } \\
\text { production } \\
\text { rate } \\
(\mu \mathrm{g} / \text { day })\end{array}$} \\
\hline & & & 1/day & $1 /$ day $\cdot \mathrm{kg}^{-1}$ & & \\
\hline 80 & 5 & Prepubertal & $3556 \pm 289^{a}$ & $159 \pm 18^{a}$ & $10 \pm 1$ & $33 \pm 3^{a}$ \\
\hline 180 & $\begin{array}{l}5 \\
4\end{array}$ & $\begin{array}{l}\text { Prepubertal } \\
\text { Postpubertal } \dagger\end{array}$ & $\begin{array}{l}5181 \pm 366^{\mathrm{b}} \\
4837 \pm 413^{\mathrm{b}}\end{array}$ & $\begin{array}{l}58 \pm 4^{b} \\
51 \pm 5^{b}\end{array}$ & $\begin{array}{l}13 \pm 2 \\
10 \pm 1\end{array}$ & $\begin{array}{l}66 \pm 12^{\mathrm{b}} \\
48 \pm 8^{\mathrm{a}, \mathrm{b}}\end{array}$ \\
\hline 260 & $\begin{array}{l}6 \\
4\end{array}$ & $\begin{array}{l}\text { Postpubertal }+ \\
\text { Pregnant } \S\end{array}$ & $\begin{array}{l}6368 \pm 513^{\mathrm{b}} \\
5787 \pm 312^{\mathrm{b}}\end{array}$ & $\begin{array}{l}55 \pm 5^{b} \\
51 \pm 4^{b}\end{array}$ & $\begin{array}{r}9 \pm 1 \\
12 \pm 4\end{array}$ & $\begin{array}{l}61 \pm 11^{\mathrm{b}} \\
69 \pm 16^{\mathrm{b}}\end{array}$ \\
\hline
\end{tabular}

*Values are mean \pm s.e.m. for the number of gilts indicated. Average weight of gilts at 80,180 and 260 days was 23,92 and $118 \mathrm{~kg}$, respectively.

$\uparrow$ Day 7 of the oestrous cycle.

$\ddagger$ Day 11 of the oestrous cycle.

$\S$ Day 30 of gestation.

${ }_{a, b}$ Values in the same column without the same superscripts differ $(P<0 \cdot 05)$.

Table 2. Metabolic clearance rate, plasma concentration and production rate of progesterone in gilts of different ages and reproductive states

\begin{tabular}{|c|c|c|c|c|c|c|}
\hline \multirow{2}{*}{$\begin{array}{l}\text { Age } \\
\text { (days) }\end{array}$} & \multirow{2}{*}{$\begin{array}{l}\text { No. of } \\
\text { gilts* }\end{array}$} & \multirow[b]{2}{*}{ Status } & \multicolumn{2}{|c|}{$\begin{array}{l}\text { Plasma metabolic } \\
\text { clearance rate }\end{array}$} & \multirow{2}{*}{$\begin{array}{l}\text { Plasma } \\
\text { progesterone } \\
\text { conc. } \\
(\mathrm{ng} / \mathrm{ml})\end{array}$} & \multirow{2}{*}{$\begin{array}{l}\text { Plasma } \\
\text { production } \\
\text { rate } \\
(\mathrm{mg} / \mathrm{day})\end{array}$} \\
\hline & & & 1/day & $1 /$ day $\cdot \mathrm{kg}^{-1}$ & & \\
\hline 80 & 5 & Prepubertal & $4132 \pm 476^{a}$ & $171 \pm 29^{a}$ & $0.05 \pm 0.01^{\mathrm{a}}$ & $0.2 \pm 0.1^{2}$ \\
\hline 180 & $\begin{array}{l}4 \\
4\end{array}$ & $\begin{array}{l}\text { Prepubertal } \\
\text { Postpubertal } \dagger\end{array}$ & $\begin{array}{l}6579 \pm 524^{b} \\
6882 \pm 651^{b}\end{array}$ & $\begin{array}{l}73 \pm 5^{b} \\
72 \pm 4^{b}\end{array}$ & $\begin{array}{c}0 \cdot 35 \pm 0 \cdot 16^{\mathrm{b}} \\
12 \cdot 1 \pm 2 \cdot 1^{\mathrm{c}}\end{array}$ & $\begin{array}{r}2 \cdot 5 \pm 1 \cdot 2^{\mathrm{b}} \\
83 \cdot 5 \pm 15 \cdot 2^{\mathrm{c}}\end{array}$ \\
\hline 260 & $\begin{array}{l}3 \\
4\end{array}$ & $\begin{array}{l}\text { Postpubertal }+ \\
\text { Pregnant§ }\end{array}$ & $\begin{array}{l}7614 \pm 881^{\mathrm{b}} \\
7714 \pm 431^{\mathrm{b}}\end{array}$ & $\begin{array}{l}68 \pm 7^{b} \\
64 \pm 4^{b}\end{array}$ & $\begin{array}{l}21 \cdot 0 \pm 2 \cdot 8^{c} \\
14 \cdot 4 \pm 1 \cdot 1^{c}\end{array}$ & $\begin{array}{l}155 \cdot 3 \pm 7 \cdot 8^{\mathrm{c}} \\
112 \cdot 1 \pm 13 \cdot 2^{\mathrm{c}}\end{array}$ \\
\hline
\end{tabular}

*Values are mean \pm s.e.m. for the number of gilts indicated. Average weight of gilts at 80,180 and 260 days was 25,92 and $117 \mathrm{~kg}$, respectively.

† Day 9 of the oestrous cycle.

$\ddagger$ Day 12 of the oestrous cycle.

$\S$ Day 32 of gestation.

a,b Values in the same column without the same superscripts differ $(P<0.05)$.

$\left[{ }^{3} \mathrm{H}\right]$ progesterone is expressed as a percentage of the radiolabelled steroid hormone determined for each gilt at $135 \mathrm{~min}$ of continuous infusion. Plasma equilibration was similar for both $\left[{ }^{3} \mathrm{H}\right]$ oestradiol and $\left[{ }^{3} \mathrm{H}\right]$ progesterone and for $80-, 180$ - and 260 -day-old gilts. Two points of evidence that steady-state conditions had been achieved were (1) from 105 to $135 \mathrm{~min}$, the percentage change was $<10 \%$, and (2) the four steady-state samples collected for MCR determinations from 145 to $175 \mathrm{~min}$ for each gilt had a coefficient of variation of $10 \%$ or less.

Metabolic clearance rates of steroid hormones were determined in both plasma and blood of unanaesthetized gilts at different ages and different reproductive states within ages. Results of this study are reported as determined in plasma because MCR estimates for plasma and for blood were consistently different $(P<0.05)$ regardless of age of gilt. Estimates of MCR were $21 \pm 1 \%$ and $27 \pm 2 \%$ less in plasma than in blood for oestradiol and progesterone, respectively. The $\left[{ }^{3} \mathrm{H}\right]$ oestradiol and $\left[{ }^{3} \mathrm{H}\right]$ progesterone recovered from blood and corrected for haematocrit, and 
$\left[{ }^{3} \mathrm{H}\right]$ oestradiol and $\left[{ }^{3} \mathrm{H}\right]$ progesterone recovered from plasma were different $(P<0.05)$ because $19 \%$ of $\left[{ }^{3} \mathrm{H}\right]$ oestradiol and $14 \%$ of $\left[{ }^{3} \mathrm{H}\right]$ progesterone in blood was associated with the cellular component.

Metabolic clearance rate of oestradiol and progesterone was lower $(P<0.05)$ for 80-day-old gilts than for older gilts (Tables $1 \& 2$ ). When adjusted for body weight, the MCR for oestradiol and progesterone in plasma was greater $(P<0.05)$ for 80 -day-old prepubertal gilts than for older gilts, independent of reproductive state (Tables $1 \& 2$ ).

Plasma concentrations and PR of oestradiol are shown in Table 1. Concentration of oestradiol ranged from 9 to $13 \mathrm{pg} / \mathrm{ml}$ for gilts of all groups. However, PR of oestradiol was lower $(P<0.05)$ for 80-day-old gilts than for older gilts except for 180-day-old postpubertal gilts. Plasma concentration and PR of progesterone are shown in Table 2. Plasma concentration and PR of progesterone were lower $(P<0.05)$ for 80 - and 180-day-old prepubertal gilts than for 180- and 260-day-old postpubertal and pregnant gilts.

\section{Discussion}

Genotype, as well as a number of environmental factors, influences the process of pubertal development in the gilt (Christenson \& Ford, 1979; Christenson, 1981), but the physiological basis of pubertal development in the gilt is not fully understood. Although several investigators (Kallas, 1929; Pfeiffer, 1936; Byrnes \& Meyer, 1951; Ramirez \& McCann, 1965; Odell \& Swerdloff, 1976) have suggested the mechanism by which puberty is attained in mammals, the most widely accepted hypothesis is a change in hypothalamic sensitivity to the negative feedback action of gonadal steroids. As an animal matures, the sensitivity of the hypothalamus to negative feedback diminishes and greater quantities of gonadal steroids are required to inhibit gonadotrophin secretion (Ramirez, 1973); this has been demonstrated for gilts (Berardinelli, Ford, Christenson \& Anderson, 1984). However, other physiological mechanisms are probably involved in pubertal development. The results of this experiment demonstrate that MCR $\left(\mathrm{l} / \mathrm{day} \cdot \mathrm{kg}^{-1}\right)$ determined in plasma for oestradiol and progesterone was significantly greater for 80 -day-old prepubertal gilts than for 180-day-old prepubertal or postpubertal gilts and for 260-day-old postpubertal and pregnant gilts. Therefore, a reduction in the MCR of gonadal steroid hormones in the gilt may be involved in maintaining steroid concentration and conserving steroids as sexual development proceeds. This study supports previous findings (Elsaesser et al., 1982; Christenson et al., 1984) which show that older, mature male and female pigs metabolize steroids (per $\mathrm{kg}$ body weight) at a slower rate than do immature pigs. Metabolic clearance rate data have been expressed on a per $\mathrm{kg}$ body weight basis to adjust the data for increases of blood volume associated with growth.

Serum concentrations of gonadal steroids in the developing pig are a result of endogenous PR and MCR and of gonadal steroid association to blood components. Although sex hormonebinding globulins can influence endogenous circulating concentrations of steroids and are species dependent (Corvol \& Bardin, 1973), these globulins have not been observed in pigs (Cook, Hunter \& Kelly, 1977). However, association of steroids to the cellular components of blood has been reported for humans (Longcope, Layne \& Tait, 1968; Little, Tait, Tait \& Erlenmeyer, 1966) and pigs (Christenson et al., 1984). In this experiment, estimates of MCR of oestradiol and progesterone were consistently lower $(21$ and $27 \%)$ in plasma than in blood, which suggests association of gonadal steroids to cellular components of blood. However, in this study and a previous study with boars (Christenson et al., 1984), the differences in MCR estimates of plasma and blood were not influenced by the age of the pig or by castration of boars. Therefore, gonadal steroid association to cellular components of blood is relatively constant and probably not a component of pubertal development.

Plasma concentrations of oestradiol and testosterone in boars increase 6-fold from 70 to 190 days of age (Allrich, Christenson, Ford \& Zimmerman, 1982; Christenson et al., 1984) and during 
pubertal development the number and weight of Leydig cells increase 8-fold (Allrich et al., 1983). During the same period of development, MCR $\left(1 /\right.$ day $\left.\cdot \mathrm{kg}^{-1}\right)$ of steroid hormones declines $1 \cdot 5-$ to 2.0-fold (Christenson et al., 1984). Therefore, steroid PR and MCR, both components of pubertal development, enhance the availability of steroids. A similar process during pubertal development of the gilt is assumed, based on a similar developmental pattern of MCR in boars and gilts, near equal MCR estimates of oestradiol for boars and gilts, and an increase in steroid PR. However, because oestradiol and progesterone concentrations remain low and relatively constant after 80 days of age in the prepubertal gilt (Wise, 1982), it is difficult to show the association of MCR and steroid availability in the gilt. In the postpubertal gilt, the reduction in MCR of oestradiol and progesterone appears to be near maximal at a time when the gilt begins to have cyclic increases of oestradiol and progesterone. Sexual differentiation of hepatic steroid metabolism has been reported for the rat (Einarsson, Gustafsson \& Stenberg, 1973; Gustafsson \& Stenberg, 1974), but similar studies have not been reported for the pig. Quantitative determination of MCR in boars suggests that removal of oestradiol and testosterone by castration (Christenson et al., 1984) did not alter MCR of oestradiol or testosterone at 180 days of age. Therefore, there is no indication that increasing oestradiol and testosterone in intact boars, or removal of oestradiol and testosterone by castration of male pigs influenced the MCR of gonadal steroids during pubertal development. Accordingly, low and static serum concentrations of oestradiol and progesterone during pubertal development in gilts would not be expected to be influencing the MCR of steroids.

Further comparisons of the estimates of MCR in the boars of a previous study (Christenson et $a l ., 1984$ ) and the gilts of the present study were not made because oestradiol was the only hormone common to both studies. However, the estimates of MCR $\left(1 / \mathrm{day}^{\prime} \mathrm{kg}^{-1}\right)$ in boars were less for testosterone than oestradiol and the estimates of $\mathrm{MCR}\left(1 / \mathrm{day} \cdot \mathrm{kg}^{-1}\right)$ in gilts were insignificantly greater for progesterone than oestradiol.

Serum concentrations of progesterone were low $(<1 \mathrm{ng} / \mathrm{ml})$ in prepubertal, 80- and 180-day-old gilts but a large change in MCR was recorded for gilts during this age span. In contrast, an acute increase in serum progesterone concentration is measured at puberty and in this experiment 180-day-old prepubertal and postpubertal gilts have a similar MCR of progesterone. In fact, MCR values are not greater in 260-day-old postpubertal gilts that have experienced at least 30-60 days of cyclic elevations in oestradiol and progesterone. Acute changes in oestradiol and progesterone serum concentrations in gilts during different physiological reproductive states are therefore unlikely to alter quantitative changes in MCR of oestradiol and progesterone. Similarly, the MCR of oestradiol is not altered by the absence of ovarian function in women (Hembree, Bardin \& Lipsett, 1969) or rhesus monkeys (Hotchkiss, 1983), during the menstrual cycle of women (Longcope et al., 1968) and rhesus monkeys (Hotchkiss, 1983), or with exogenous oestradiol treatment of women (Hembree et al., 1969).

The results of this study support the finding that the MCR of oestradiol is greater in prepubertal than peripubertal gilts (Elsaesser et al., 1982) and extends our knowledge to include both oestradiol and progesterone in gilts of three ages and three reproductive states. The results support the hypothesis that a reduction in metabolism of gonadal steroids, regardless of the existence of different gonadal steroid profiles in male and female pigs during pubertal development, may allow gonadal steroids to advance sexual development. Coupled with reduced metabolism of gonadal steroids are other physiological components also associated with sexual maturation.

We thank Bruce Larsen and Suzy Reece for animal care, Toni Tolles and Ann Hultine for laboratory expertise, and Kathy Leising and Linda Parnell for typing the manuscript. We acknowledge the co-operation of the University of Missouri-Columbia and of the Agricultural Experiment Station, University of Nebraska-Lincoln.

Mention of trade names or companies does not constitute an implied warrant or endorsement by the U.S.D.A. or the authors. 


\section{References}

Allrich, R.D., Christenson, R.K., Ford, J.J. \& Zimmerman, D.R. (1982) Pubertal development of the boar: testosterone, estradiol-17ß, cortisol and $\mathbf{L H}$ concentrations before and after castration at various ages. J. Anim. Sci. 55, 1139-1146.

Allrich, R.D., Christenson, R.K., Ford, J.J. \& Zimmerman, D.R. (1983) Pubertal development of the boar: age-related changes in testicular morphology and in vitro production of testosterone and estradiol-17ß. Biol. Reprod. 28, 902-909.

Berardinelli, J.G., Ford, J.J., Christenson, R.K. \& Anderson, L.L. (1984) Luteinizing hormone secretion in ovariectomized gilts: effects of age, reproductive state and estrogen replacement. J. Anim. Sci. 58, $165-173$.

Byrnes, W.W. \& Meyer, R.K. (1951) The inhibition of gonadotrophic hormone secretion by physiological doses of estrogen. Endocrinology 48, 133-136.

Carr, B.R., Mikhail, G. \& Flickinger, G.L. (1971) Column chromatography of steroids on Sephadex LH-20. J. clin. Endocr. Metab. 33, 358-360.

Christenson, R.K. (1981) Influence of confinement and season of the year on puberty and estrous activity of gilts. J. Anim. Sci. 52, 821-830.

Christenson, R.K. \& Ford, J.J. (1979) Puberty and estrus in confinement-reared gilts. J. Anim. Sci. 49, 743-751.

Christenson, R.K., Ford, J.J. \& Redmer, D.A. (1984) Estradiol and testosterone metabolic clearance and production rates during puberal development in boars. Biol. Reprod. 31, 905-912.

Colby, H.D. (1980) Regulation of hepatic drug and steroid metabolism by androgens and estrogens. In Advances in Sex Hormone Research, pp. 27-71. Eds J. A. Thomas \& R. L. Singhal. Urban \& Schwarzenberg, Baltimore.

Cook, B., Hunter, R.H.F. \& Kelly, A.S.L. (1977) Steroidbinding proteins in follicular fluid and peripheral plasma from pigs, cows and sheep. J. Reprod. Fert. 51, 65-71.

Corvol, P. \& Bardin, C.W. (1973) Species distribution of testosterone-binding globulin. Biol. Reprod. 8, $277-282$.

Einarsson, K., Gustafsson, J.-A. \& Stenberg, A. (1973) Neonatal imprinting of liver microsomal hydroxylation and reduction of steroids. J. biol. Chem. 248, 4987-4997.

Elsaesser, F., Stickney, K. \& Foxcroft, G. (1982) A comparison of metabolic clearance rates of oestradiol$17 \beta$ in immature and peripubertal female pigs and possible implications for the onset of puberty. Acta endocr., Copenh. 100, 606-612.
Gustafsson, J.-A. \& Stenberg, A. (1974) Irreversible androgenic programming at birth of microsomal and soluble rat liver enzymes active on 4-androstene-

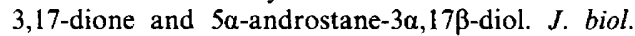
Chem. 249, 711-718.

Hembree, W.C., Bardin, C.W. \& Lipsett, M.B. (1969) A study of estrogen metabolic clearance rates and transfer factors. J. clin. Invest. 48, 1809-1819.

Hotchkiss, J. (1983) The metabolic clearance rate and the production rate of estradiol in sexually immature and adult fermale Rhesus monkeys. J. clin. Endocr. Metab. 56, 979-984.

Kallas, H. (1929) Puberte precoce par parabiose. C. $r$. Séanc. Soc. Biol. 100, 979-980.

Little, B., Tait, J.F., Tait, S.A.S. \& Erlenmeyer, F. (1966) The metabolic clearance rate of progesterone in males and ovariectomized females. J. clin. Invest. 45, 901-912.

Longcope, C., Layne, D.S. \& Tait, J.F. (1968) Metabolic clearance rates and interconversions of estrone and $17 \beta$-estradiol in normal males and females. $J$. clin. Invest. 47, 93-106.

Odell, W.D. \& Swerdloff, R.S. (1976) Etiologies of sexual maturation: a model system based on the sexually maturing rat. Recent Prog. Horm. Res. 32, 245-288.

Pfeiffer, C.A. (1936) Sexual differences of the hypophyses and their determination by the gonads. Am. J. Anat. 58, 195-225.

Ramirez, V.D. (1973) Endocrinology of puberty. In Handbook of Physiology, Vol. II, pp. 1-28. Eds R. O. Greep \& E. B. Astwood. American Physiological Society, Washington, DC.

Ramirez, V.D. \& McCann, S.M. (1965) Inhibitory effect of testosterone on luteinizing hormone secretion in immature and adult rats. Endocrinology 76, 412-417.

Steel, R.G.D. \& Torrie, J.H. (1960) Principles and Procedures of Statistics. McGraw-Hill Book Co., New York.

Tait, J.F. (1963) Review: the use of isotopic steroids for the measurement of production rates in vivo. J. clin. Endocr. Metab. 23, 1285-1297.

Wise, M.E. (1982) Pubertal development of the gilt: characterization of gonadotropic and gonadal hormones and the negative and positive regulation of LH and FSH. Ph.D. dissertation, University of Nebraska, Lincoln.

Received 29 January 1985 